\title{
Perbandingan Hasil Belajar IPA Dengan Metode Snowball Throwing Dan Konvensional Pada Siswa Kelas V SD Negeri 58 Kota Bengkulu
}

\author{
Abdul Aziz Bin Mustamin ${ }^{1}$, Ahmad Walid ${ }^{2}$, Adrian Topano ${ }^{3}$, Asiyah $^{4}$ \\ ${ }^{1234}$ Program Studi Pendidikan IPA IAIN Bengkulu \\ Alamat email koresponden: ${ }^{1}$ abdulazizm@iainbengkulu.ac.id \\ diterima: 10 Agustus 2019, disetujui: 15 Agustus 2019, dipublikasikan: 30 September 2019
}

\begin{abstract}
Abstrak
Tujuan penelitian ini yaitu apakah terdapat perbedaan hasil belajar IPA dengan metode snowball throwing dan konvensional siswa kelas V SD Negeri 58 Kota Bengkulu. Jenis penelitian ini adalah penelitian lapangan dengan pendekatan quasi eksperimental yang mengungkap hubungan antara dua variabel atau lebih atau mencari pengaruh suatu variabel terhadap variabel lainnya. Hasil penelitian disimpulkan bahwa terdapat terdapat perbedaan hasil belajar IPA dengan metode snowball throwingdan metode konvensional siswa kelas V SD Negeri 58 Kota Bengkulu. Hal ini dapat dilihat dari hasil analisis untuk uji-t diperoleh nilai signifikansi yang diperoleh yaitu 0,00 lebih kecil dari 0,05 ( $\mathrm{sig}<0,05$ ). Dengan demikian dapat dinyatakan bahwa hipotesis alternatif (Ha) diterima dan hipotesis nihil (Ho) ditolak, yang artinya terdapat perbedaan hasil belajar IPA dengan metode snowball throwingdan metode konvensional siswa kelas V SD Negeri 58 Kota Bengkulu.

Kata Kunci: Metode Snowball Throwing, Metode Konvensioanl, Hasil Belajar, IPA
\end{abstract}

\section{Comparison Of Science Learning Outcomes With Convention And Snowball Throwing Methods In Students Class V Of SD Negeri 58 Bengkulu}

\author{
Daeng Aziz ${ }^{1}$, Ahmad Walid ${ }^{2}$, Adrian Topano ${ }^{3}$, Asiyah ${ }^{4}$ \\ ${ }^{1}$ Department of Science Education, ${ }^{2}$ IAIN Bengkulu, ${ }^{3}$ Raden Fatah Street, ${ }^{4}$ Pagar Dewa, Bengkulu 38211, Indonesia \\ Email address of the correspondents: ${ }^{1}$ abdulazizm@iainbengkulu.ac.id

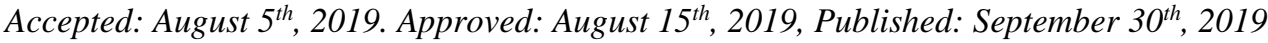

\begin{abstract}
The purpose of this study is whether there are differences in learning outcomes of science with snowball throwing methods and conventional fifth grade students of SD Negeri 58 Bengkulu City. This type of research is field research with a quasi-experimental approach that reveals the relationship between two or more variables or looks for the influence of a variable on other variables. The results of the study concluded that there were differences in science learning outcomes with the snowball throwing method and the conventional methods of fifth grade students of SD Negeri 58 Bengkulu City. This can be seen from the results of the analysis for the t-test the significance value obtained is 0.00 less than 0.05 (sig $<0.05)$. Thus it can be stated that the alternative hypothesis $(\mathrm{Ha})$ is accepted and the null hypothesis (Ho) is rejected, which means that there are differences in science learning outcomes with the snowball throwing method and the conventional method of fifth grade students of SD Negeri 58 Bengkulu City. Keywords: Snowball Throwing Method, Conventional Methods, Learning Outcomes, Science
\end{abstract}




\section{PENDAHULUAN}

Perkembangan ilmu pengetahuan dan teknologi telah membawa perubahan hampir disemua aspek kehidupan, di mana berbagai permasalahan hanya dapat dipecahkan dengan penguasaan dan peningkatan ilmu pengetahuan dan teknologi. (Walid, A., dkk, 2019)

Keberhasilan dan kualitas pendidikan dipengaruhi oleh berbagai faktor seperti sistem pendidikan, sarana dan prasarana pendidikan, kualitas dan profesionalisme guru, kurikulum yang sedang digunakan, serta kualitas pembelajaran. Terlepas faktor mana yang menjadi penentu utama, kualitas pembelajaran tetap memengang porsi yang besar terhadap keberhasilan dan kualitas hasil pendidikan (Muhibbin, 2009).

Peningkatan kualitas pendidikan merupakan dampak logis dari pembelajaran yang baik. Pembelajaran yang baik mengharuskan penyesuaian dan peningkatan proses pembelajaran secara terus menerus. Disamping itu, perlu adanya perbaikan dalam pemilihan konsep-konsep pembelajaran yang digunakan untuk meningkatkan kualitas lulusan itu sendiri

Akan tetapi, sampai saat ini tujuan tersebut belum tercapai secara maksimal. Salah satu faktor penyebabnya adalah mata pelajaran IPA dianggap sebatas memuat materi berupa fakta, konsep, dan prinsipprinsip.

Selain itu, dalam pembelajaran IPA sebagian besar masih mempertahankan urutan-urutan dalam buku serta kurang memperdulikan kesesuaian dengan lingkungan belajar siswa. Hal ini membuat pembelajaran tidak efektif, karena siswa kurang merespon terhadap pelajaran yang disampaikan. Pengajaran semacam ini cenderung mematikan motivasi siswa.

Kondisi siswa yang pasif menyebabkan materi pelajaran yang dipelajari siswa tidak berkesan pada diri siswa. Dengan demikian, pembelajaran tersebut tidak menghasilkan prestasi belajar yang baik. Kurangnya perhatian dan minat siswa terhadap mata pelajaran IPA juga berpengaruh terhadap prestasi belajar siswa (Trianto, 2009).

Pada hakikatnya siswa telah memiliki kemampuan awal yang diterima di kelas sebelumnya. Kemampuan awal siswa ini harus digali agar siswa lebih belajar mandiri dan kreatif, khususnya ketika mereka akan mengkaitkan pengetahuan yang mereka miliki dengan pelajaran baru. Salah satu cara yang dapat ditempuh adalah menggunakan pembelajaran yang mendekatkan siswa pada lingkungan.

Pembelajaran bukan hanya
mendengarkan dan mencatat, tetapi merupakan proses pencarian pengalaman secara langsung. Melalui proses ini diharapkan siswa tidak hanya mengembangkan aspek kognitif saja tetapi juga mengembangkan aspek afektif dan psikomotor. Hal ini, tentunya akan membentuk pembelajaran dan proses belajar yang sesungguhnya bagi diri peserta didik.

Efek lain adalah timbulnya motivasi belajar dari dalam diri siswa, karena siswa berandil besar dalam pembelajaran, bukan hanya sebagai "penerima" tetapi sebagai actor yang aktif. Dengan adanya motivasi 
belajar siswa yang tinggi diharapkan dapat meningkatkan hasil dan prestasi belajar siswa (Walid, A., Sajidan, S., \& Ramli, M, 2015)

Metode mengajar yang guru gunakan dalam setiap kali pertemuan kelas bukanlah asal pakai, tetapi telah melalui seleksi yang berkesesuaian dengan perumusan tujuan intruksional khusus. Jarang sekali terlihat guru merumuskan tujuan hanya dengan satu rumusan, tetapi pasti guru merumuskan lebih dari satu tujuan. Karenanya, guru pun selalu menggunakan metode yang lebih dari satu. Pemakaian metode yang satu digunakan untuk mencapai tujuan yang satu, sementara penggunaan metode yang lain, juga digunakan untuk mencapai tujuan yang lain. Begitulah adanya, sesuai dengan kehendak tujuan pengajaran yang telah dirumuskan.

\section{METODE}

Jenis penelitian ini adalah penelitian lapangan dengan pendekatan quasi eksperimental yang mengungkap hubungan antara dua variabel atau lebih atau mencari pengaruh suatu variabel terhadap variabel lainnya.

Dalam penelitian ini, sampel dibagi menjadi dua kelompok eksperimen yang diberi perlakuan dengan metode snowball throwing dan kelompok kontrol dengan metode konvensional. Desain penelitian yang digunakan dalam penelitian ini adalah Nonequivalent control group posstest design.

Populasi dalam penelitian ini adalah siswa kelas V SD Negeri 58 Kota Bengkulu yang terdiri dari 4 kelas yaitu kelas $\mathrm{V} \mathrm{A}, \mathrm{V}$ 90
B, V C dan V D. Sedangkan sampel dalam penelitian ini adalah siswa kelas V A dan V B yang masing-masing berjumlah 30 orang.

Teknik pengumpulan data menggunakan observasi, test dan dokumentasi. Instrumen yang digunakan dalam penelitian ini yaitu lembar pre-test dan post-test. Teknik analisis data menggunakan uji prasyarat yakni uji normalitas dan homogenitas, sedangkan uji hipotesis menggunakan uji anova dan uji lanjut menggunakan uji LSD.

\section{HASIL DAN PEMBAHASAN}

\section{Pelaksanaan Perlakuan}

Pada penelitian ini penulis bertindak sebagai observer. Kegiatan yang dilakukan pada tahapan perencanaan penelitian ini yaitu menyiapkan silabus, Rencana Pelaksanaan Pembelajaran (RPP), membuat pedoman penilaian, menyiapkan materi yang sesuai dengan kompetensi yang akan diajarkan, membuat media pembelajaran dan lembar kerja siswa (LKS).

Pada penelitian quasi eksperimen ini digunakan pembelajaran dengan metode snowball throwingpada siswa kelas V SD Negeri 58 Kota Bengkulu yang berjumlah 30 orang siswa yang dilaksanakan selama dua jam pelajaran dengan alokasi waktu 2 x 35 menit (90 menit). Kegiatan awal pembelajaran menggunakan SD Negeri 58 Kota Bengkuludi kelas dimulai dengan menyiapkan pembelajaran sebagaimana biasanya, guru melakukan apersepsi dan menugaskan siswa untuk mengemukakan pendapatnya masing-masing. Tujuan dari kegiatan ini adalah untuk membangkitkan http://journal.univetbantara.ac.id/index.php/JBL/ 
ide-ide siswa. Setelah hal tersebut dilakukan siswa menyusun beberapa pertanyaan atas jawaban yang ingin diketahui pada lembar pertanyaan yang dibagikan guru, sehingga dari pertanyaan tersebut terbentuklah tujuan membaca. Tujuannya adalah untuk membangkitkan rasa ingin tahu siswa. Setelah selesai, siswa diharuskan menjawab pertanyaan tadi yang sebelumnya telah diformulasikan oleh guru melalui aktivitas cara membaca materi. Jawaban tersebut selanjutnya disusun menjadi ringkasan bacaan untuk kemudian diceritakan dan disampaikan kembali oleh siswa di depan kelas. Setelah kegiatan tersebut selesai dilaksanakan guru bersama siswa mengkonfirmasikan hasil pembelajaran yang telah berlangsung dan memberikan penguatan kepada siswa.

\section{Observasi}

Pada saat pemberian perlakuan (treatment) dengan menggunakan metode snowball throwingpeneliti melakukan pengamatan (observasi) tentang aktivitas guru dan aktivitas siswa selama proses pembelajaran berlangsung. Observasi ini bertujuan untuk mengetahui apakah pembelajaran sudah sesuai dengan langkahlangkah yang sudah direncanakan atau belum. Dalam penelitian ini, peneliti dibantu oleh guru kelas.

Berdasarkan data pada di atas, hasil pengamatan aktivitas terhadap guru yaitu peneliti yang melaksanakan metode snowball throwing yang dilakukan oleh satu orang guru menunjukkan bahwa guru sudah benar-benar dapat berperan dengan baik dalam semua dengan menggunakan metode metode snowball throwing. Hasil observasi terhadap aktivitas siswa dalam penerapan metode snowball throwingpada pelajaran PAI berjalan dengan baik.

\section{Hasil Tes}

Berdasarkan hasil tes belajar didapatkan sebagai berikut: 1) Hasil Tes Kelas Kontrol, Berdasarkan hasil tes belajar awal kelas kontrol yang melaksanakan pembelajaran IPA dengan menggunakan metode konvensional dapat diketahui bahwa dari nilai tes pada siswa yaitu dari 30 siswa diperoleh nilai rata-rata adalah 69,66; 2) Hasil tes Kelas Eskperimen, Berdasarkan hasil tes belajar awal kelas eksperimen yang melaksanakan pembelajaran IPA dengan menggunakan metode snowball throwing dapat diketahui bahwa dari nilai tes pada siswa yaitu dari 30 siswa diperoleh nilai ratarata adalah 76,16; 3) Uji Normalitas dan Homogenitas Data.

\section{Uji Normalitas}

Hasil uji normalitas dapat dilihat pada Tabel 1.

Tabel 1. Tests of Normality ${ }^{b}$

\begin{tabular}{|c|c|c|c|c|c|c|c|}
\hline & \multirow[b]{2}{*}{$\mathrm{Y}$} & \multicolumn{3}{|c|}{ Kolmogorov-Smirnov ${ }^{a}$} & \multicolumn{3}{|c|}{ Shapiro-Wilk } \\
\hline & & Statistic & $\mathrm{df}$ & Sig. & Statistic & df & Sig. \\
\hline \multirow[t]{4}{*}{$\mathrm{X}$} & 60 & .329 & 4 & . & .895 & 4 & .406 \\
\hline & 65 & .250 & 4 & . & .945 & 4 & .683 \\
\hline & 70 & .225 & 13 & .072 & .865 & 13 & .045 \\
\hline & 75 & .231 & 8 & $.200^{*}$ & .800 & 8 & .028 \\
\hline \multicolumn{8}{|c|}{ a. Lilliefors Significance Correction } \\
\hline \multicolumn{8}{|c|}{ *. This is a lower bound of the true significance. } \\
\hline \multicolumn{8}{|c|}{$\begin{array}{l}\text { b. } X \text { is constant when } Y=85,00 \text {. It has been } \\
\text { omitted. }\end{array}$} \\
\hline
\end{tabular}

Dari Tabel 1 dapat diketahui bahwa nilai signifikansi dari masing-masing variabel menunjukkan lebih besar dari nilai 0,05 . Adapun untuk nilai signifikansi yang diperoleh lebih besar dari 0,05 maka dapat 
disimpulkan bahwa data yang diuji berdistribusi normal.

\section{Uji Homogenitas}

Hasil uji homogenitas dapat dilihat pada Tabel 2.

Tabel 2. Test of Homogeneity of Variance ${ }^{a}$

\begin{tabular}{|c|c|c|c|c|c|}
\hline & & $\begin{array}{l}\text { Levene } \\
\text { Statistic }\end{array}$ & df1 & df2 & Sig. \\
\hline \multirow[t]{4}{*}{$\mathrm{X}$} & Based on Mean & 1.512 & 3 & 25 & .236 \\
\hline & Based on Median & 1.251 & 3 & 25 & .313 \\
\hline & $\begin{array}{l}\text { Based on Median and } \\
\text { with adjusted df }\end{array}$ & 1.251 & 3 & 20.668 & .317 \\
\hline & $\begin{array}{l}\text { Based on trimmed } \\
\text { mean }\end{array}$ & 1.463 & 3 & 25 & .248 \\
\hline
\end{tabular}

a. $\mathrm{X}$ is constant when $\mathrm{Y}=85,00$. It has been omitted.

Dari table 2 dapat diketahui bahwa nilai signifikansi dari masing-masing variabel menunjukkan lebih besar dari nilai 0,05 . Adapun untuk nilai signifikansi yang diperoleh lebih besar dari 0,05 maka dapat disimpulkan bahwa data yang diuji akan variansi setiap sampel sama (homogen); 4) Uji Hipotesis Penelitian

Tabel 3. Paired Samples Test

\begin{tabular}{|c|c|c|c|c|c|c|c|}
\hline \multicolumn{8}{|c|}{ Paired Samples Test } \\
\hline \multicolumn{8}{|c|}{ Paired Differences } \\
\hline \multirow[b]{2}{*}{ Mean } & \multirow{2}{*}{$\begin{array}{l}\text { Std. } \\
\text { Mean }\end{array}$} & \multirow{2}{*}{ Error } & $\begin{array}{l}95 \% \\
\text { Interval } \\
\text { Difference }\end{array}$ & $\begin{array}{l}\text { Confidence } \\
\text { of the }\end{array}$ & \multirow{2}{*}{\multicolumn{2}{|c|}{ df }} & \multirow{2}{*}{$\begin{array}{l}\text { Sig. } \\
\text { tailed) }\end{array}$} \\
\hline & & & Lower & Upper & & & \\
\hline-6.50 & 1.48072 & & -9.52841 & -3.47159 & -4.39 & 29 & .000 \\
\hline
\end{tabular}

Berdasarkan Tabel 3, hasil analisis untuk Uji-t diperoleh nilai signifikansi yang diperoleh yaitu 0,00 lebih kecil dari 0,05 (sig $<0,05)$. Dengan demikian dapat dinyatakan bahwa hipotesis alternatif (Ha) diterima dan hipotesis nihil (H0) ditolak, yang artinya terdapat perbedaan hasil belajar IPA dengan metode snowball throwingdan metode konvensional siswa kelas V SD Negeri 58 Kota Bengkulu.

Berdasarkan hasil penelitian dan analisis data yang telah dilakukan maka dapat diketahui bahwa terdapat perbedaan hasil belajar IPA dengan metode snowball throwingdan metode konvensional siswa kelas V SD Negeri 58 Kota Bengkulu. Metode Snowball throwingadalah suatu metode penyajian bahan pelajaran dimana siswadibentukdalam beberapa kelompok yang heterogen kemudian masing-masing kelompok dipilih ketua kelompoknya untuk mendapat tugas dari guru lalu masingmasing murid membuat pertanyaan yang dibentuk seperti bola (kertas pertanyaan) kemudian dilempar ke murid lain yang masing-masing murid menjawab pertanyaan dari bola yang diperoleh.

Hasil penelitian diperoleh nilai hasil belajar IPA siswa kelas VB sebagai kelas kontrol di SD Negeri 58 Kota Bengkulu yaitu sebesar 69,66 sedangkan nilai hasil belajar siswa kelas V A sebagai kelas ekperimen diperoleh rata-rata yaitu 76,16. Dari kedua nilai rata-rata ini dapat dilihat adanya perbedan yang signifikan yaitu nilai kelas kontrol yang menggunakan metode konvensionaldan kelas eksperimen setelah dilakukan pembelajaran IPA dengan menggunakan metode metode Snowball throwinglebih tinggi jika nilai kelas kontrol.

Hasil analisis uji t dari 0,05 (sig < 0,05). Dengan demikian dapat dinyatakan bahwa hipotesis alternatif (Ha) diterima dan hipotesis nihil (H0) ditolak, yang artinya terdapat perbedaan hasil belajar IPA dengan 
metode snowball throwingdan metode konvensional siswa kelas V SD Negeri 58 Kota Bengkulu.

Dengan demikian berdasarkan perbandingan hasil belajar dan peningkatan hasil belajar siswa di atas menujukkan bahwa kelebihan-kelebihan metode snowball throwing dapat diaplikasikan dalam pembelajaran IPA sebagaimana dijelaskan oleh Suprijono bahwa metodesnowball throwingmemiliki kelebihan dan kelemahan. Kelebihan yang ditemukan dalam pelaksanaan pembelajaran metode snowball throwing diantaranya: 1) Melatih kesiapan Siswa dalam merumuskan pertanyaan dengan bersumber pada materi yang diajarkan serta saling memberikan pengetahuan; 2) Siswa lebih memahami dan mengerti secara mendalam tentang materi pelajaran yang dipelajari. Hal ini disebabkan karena murid mendapat penjelasan dari teman sebaya yang secara khusus disiapkan oleh guru serta mengerahkan penglihatan, pendengaran, menulis dan berbicara mengenai materi yang didiskusikan dalam kelompok; 3) Dapat membangkitkan keberanian siswa dalam mengemukakan pertanyaan kepada teman lain maupun guru; 4) Melatih murid menjawab pertanyaan yang diajukan oleh temannya dengan baik; 5) Merangsang siswa mengemukakan pertanyaan sesuai dengan topik yang sedang dibicarakan dalam pelajaran tersebut; 6) Dapat mengurangi rasa takut siswa dalam bertanya kepada teman maupun guru; 7) Siswa akan lebih mengerti makna kerjasama dalam menemukan pemecahan suatu masalah; 8) Siswa akan memahami makna tanggung jawab; 9) Siswa akan lebih bisa menerima keragaman atau heterogenitas suku, sosial,budaya, bakat dan intelegensia; 10) Siswa akan terus termotivasi untuk meningkatkan kemampuannya Suprijono, 2017).

Kedudukan metode dalam pembelajaran sangat penting, hal ini dikarenakan metode pembelajaran dapat meningkatkan motivasi belajar siswa sebagaimana dijelaskan oleh Syaiful Bahsi Djamarah bahwa sebagai salah satu komponen pengajaran, metode menempati peranan yang tidak kalah pentingnya dari komponen lainnya dalam kegiatan belajar mengajar. Tidak ada satupun kegiatan belajar mengajar yang tidak menggunakan metode pengajaran. Ini berarti guru memahami benar kedudukan metode sebagai alat motivasi ekstrinsik dalam kegaiatn belajar mengajar. Motivasi ekstrinsik adalah motif-motif yang aktif dan berfungsinya, karena adanya perangsang dari luar. Karena itu, metode berfungsi sebagai alat perangsang dari luar yang dapat membangkitkan belajar seseorang (Djamarah dkk., 2006).

\section{KESIMPULAN DAN SARAN}

Berdasarkan penelitian yang penulis lakukan maka dapat disimpulkan bahwa terdapat perbedaan hasil belajar IPA dengan metode snowball throwing dan metode konvensional siswa kelas V SD Negeri 58 Kota Bengkulu. Hal ini dapat dilihat dari hasil analisis untuk uji-t diperoleh nilai signifikansi yang diperoleh yaitu 0,00 lebih kecil dari 0,05 (sig < 0,05). Dengan demikian dapat dinyatakan bahwa hipotesis 
alternatif (Ha) diterima dan hipotesis nihil (Ho) ditolak, yang artinya terdapat perbedaan hasil belajar IPA dengan metode snowball throwing dan metode konvensional siswa kelas V SD Negeri 58 Kota Bengkulu.

\section{DAFTAR PUSTAKA}

Asiyah, A., \& Walid, A. (2018). Pengembangan Modul Berbasis Challenge Based Learning Materi Lingkungan untuk Memberdayakan Kemampuan Interpretasi dan Sikap Peduli Lingkungan Siswa. At-Ta'lim: Media Informasi Pendidikan Islam, 16(2), 275-288.

Djamarah, Bahri, S., dan Zain, A. (2006). Strategi Belajar Mengajar. Jakarta: Rineka Cipta.

Khasanah, N., Sajidan, S., Sutarno, S., Prayitno, B. A., \& Walid, A. (2019). Critical Thinking Ability and Student's Personal Religious Beliefs: An Analysis of DBUS Model Implementation. Tadris: Jurnal Keguruan dan Ilmu Tarbiyah, 4(1), 41-49.

Muhibbin, S. (2009). Psikologi Pendidikan dengan Pendekatan Baru. Bandung: Rosda.

Suprijono, A. (2017). Cooperative Learning. Yogyakarta: Putaka Pelajar.

Trianto. (2009). Mendesain Model Pembelajaran Inovatif-Progresif. Jakarta: Kencana.

Walid, A., Sajidan, S., \& Ramli, M. Constructing A Test for Assessing Higher Order Thinking Skills of High School Students on Reproductive System. In Proceeding Biology Education Conference: Biology, Science, Enviromental, and Learning (Vol. 12, No. 1, pp. 371-377).

Walid, A., Sajidan, S., Ramli, M., \& Kusumah, R. G. T. Construction of The Assessment Concept to Measure Students' High Order Thinking Skills. Journal for the Education of Gifted Young Scientists, 7(2), 237-251. 